\title{
PENGARUH PENERAPAN MODEL PEMBELAJARAN KOOPERATIF TIPE TGT (TEAM GAMES TOURNAMENT) DENGAN MEDIA MOLYMOD TERHADAP HASIL BELAJAR KIMIA
}

\author{
Nur Azmiati ${ }^{1}$, Miterianifa ${ }^{2}$ \\ ${ }^{1}$ Prodi Pendidikan Kimia Fakultas Tarbiyah dan Keguruan \\ Email: nur_azmiati@yahoo.co.id \\ ${ }^{2}$ Prodi Pendidikan Kimia Fakultas Tarbiyah dan Keguruan \\ Universitas Islam Negeri Sultan Syarif Kasim Riau
}

\begin{abstract}
This research was a quasi-experiment-instigated by the low of students' chemistry achievement. This research aimed at knowing the effect of using Team Games Tournament (TGT) type of Cooperative Learning Model with Molymod media tomard students' achievement of X grade at Senior High School of YLPI Pekanbaru. The samples of this research were Random Sampling comprising 2 classes - $X_{1}$ (Experimental group) and $X_{3}$ (Control group). There were 4 meetings done. Test, interview, questionnaire, and documentation were the techniques of collecting the data. T-test formula was used to find out the result of students' achievement. Based on the data analysis, it can be stated that $t_{\text {observed }}$ was 4.14 and $t_{\text {table }} 2.00$ and it showed that $t_{\text {observed }}$ was higher than $t_{\text {table. }}$. It revealed that $H_{o}$ was rejected and $H_{a}$ was accepted. In other words, there was a significant effect of using Team Games Tournament (TGT) type of Cooperative Learning model with Molymod media toward students' achievement of X grade at Senior High School of YLPI Pekanbaru with coefficient effect $20 \%$.
\end{abstract}

Keywords: Team Games Tournament (TGT) of Cooperative Learning Model, Molymod Media, Achievement.

\section{PENDAHULUAN}

Belajar adalah proses perubahan perilaku berkat pengalaman dan pelatihan dan belajar adalah proses perubahan melalui kegiatan atau prosedur latihan di dalam laboratorium maupun dalam lingkungan alamiah.[1] Dalam proses belajar, siswa mengasah kemampuan mentalnya untuk mempelajari pelajaran. Adanya informasi tentang sasaran belajar, evaluasi dan keberhasilan belajar membuat siswa semakin sadar akan kemampuan dirinya. Dalam proses belajar tidak terlepas dari peran guru.

Guru merupakan ujung tombak dalam proses pembelajaran, yang bertanggung jawab membentuk kepribadian siswa agar mampu memahami nilai-nilai luhur bangsa. Sebagai pengelola pengajaran, seorang guru harus mampu mengelola seluruh proses kegiatan pembelajaran dengan menciptakan kondisi-kondisi belajar sedemikian rupa sehingga setiap siswa dapat belajar secara efektif dan efisien.[2]

Untuk dapat menyampaikan materi pelajaran dengan efektif dan efisien, guru perlu mengenal berbagai jenis strategi pembelajaran untuk mempermudah proses pembelajaran sehingga siswa dapat mencapai hasil belajar yang optimal.

Hasil belajar merupakan hasil yang dicapai siswa dalam belajar, yang menunjukkan taraf kemampuan siswa dalam mengikuti program belajar dalam waktu tertentu sesuai dengan kurikulum yang telah ditentukan.

Pendidikan formal di mulai pada tingkat sekolah dasar, sekolah menengah, sampai pada tingkat perguruan tinggi, dan di antara 
beberapa ilmu yang dipelajari di sekolah, juga termasuk di dalamnya ilmu yang membahas tentang alam dan berbagai proses kejadian, ini disebut dengan mata pelajaran Ilmu Pengetahuan Alam (IPA).

Ilmu kimia merupakan bagian dari Ilmu Pengetahuan Alam yang membahas tentang susunan (struktur), perpindahan atau perubahan bentuk dan energetika zat. Untuk mempelajari ilmu kimia di sekolah diperlukan keterampilan dan penalaran.[3] Salah satu materi Kimia di SMA adalah hidrokarbon. Materi hidrokarbon merupakan materi berisi konsep dan hapalan yang membutuhkan kemampuan berpikir. Seorang siswa membutuhkan kemampuan berpikir yang baik, kemampuan analisis dan kekuatan memori untuk memahami materi hidrokarbon. Jadi, untuk mengajarkan materi hidrokarbon kepada siswa diperlukan model pembelajaran yang melibatkan siswa dalam memperoleh pengetahuan atau konsep sehingga dapat lebih dipahami dan lama di ingat siswa.

SMA YLPI Pekanbaru merupakan salah satu SMA yang berada dikota Pekanbaru. Dari hasil wawancara peneliti pada bulan Januari 2016 dengan guru bidang studi kimia di SMA YLPI didapatkan informasi bahwa pada saat guru menjelaskan materi, ada sebagian siswa yang tidak memperhatikannya, sehingga siswa tersebut kurang mengerti dengan materi yang dijelaskan guru dan apabila diberi tugas tidak semua siswa yang bisa mengerjakan tugas tersebut. Ketika siswa ditanya dan diminta untuk bertanya tentang materi yang belum dimengerti, ada sebagian siswa tidak mau bertanya dan tidak bisa menjawab hal ini dikarenakan siswa tersebut malu ataupun takut untuk bertanya langsung kepada guru. Sehingga guru merasa kesulitan untuk dapat mengetahui seberapa paham siswa dalam materi yang disampaikan. Selama ini proses pembelajaran masih didominasi oleh guru sehingga siswa lebih terbiasa belajar secara individu dan tidak terbiasa untuk bertanya kepada teman mereka untuk saling bertukar pikiran dalam belajar kelompok. Untuk membiasakan siswa bertukar pikiran dengan temannya digunakanlah model pembelajaran.

Salah satu model pembelajaran yang diharapkan dapat membiasakan siswa untuk saling bertukar pikiran dengan temannya dalam kelompok adalah model pembelajaran kooperatif tipe TGT (Team Games Tournament). TGT merupakan salah satu model pembelajaran kooperatif yang terdiri dari sistem belajar kelompok dan evaluasi yang terdiri dari permainan dan pertandingan yang dimainkan oleh masing-masing siswa yang duduk dalam kelompok.[4] Di dalam kelompok masing-masing siswa mempunyai tanggung jawab untuk mengajarkan teman dalam satu kelompoknya tentang pokok bahasan yang sedang dibahas dan setiap siswa mempunyai kesempatan menjadi perwakilan kelompoknya pada saat permainan dan pertandingan nantinya. Skor yang didapat pada saat permainan dan pertandingan menentukan skor kelompok. Jadi, dalam TGT siswa yang kurang paham akan berusaha memahami pokok bahasan yang dipelajari saat itu dan akan berusaha bertanya kepada teman yang lebih paham darinya. Sehingga setiap siswa akan paham terhadap pokok bahasan pada hari itu.

Model kooperatif tipe TGT bisa menggunakan media sebagai alat bantu dalam proses pembelajaran. Melalui media pembelajaran, guru dapat menyajikan bahan pelajaran yang bersifat abstrak menjadi konkret sehingga mudah dipahami. Hidrokarbon yang bersifat abstrak dapat dipahami lebih mudah, jika materi ini dijelaskan melalui media. Salah satu media yang dapat digunakan adalah molymod.

Molymod adalah suatu alat peraga untuk menggambarkan model suatu molekul. Melalui Molymod, siswa diharapkan dapat melihat secara langsung struktur molekul dari senyawa hidrokarbon, sehingga siswa lebih mudah memahami materi hidrokarbon.[5] Dengan demikian, diyakini bahwa melalui penerapan model pembelajaran kooperatif tipe TGT (Team Games Tournament) dengan 
media molymod dapat meningkatkan hasil belajar Kimia siswa.

Sebagaimana penelitian Wiwit, dkk, berdasarkan hasil penelitiannya menyimpulkan bahwa penerapan model pembelajaran kooperatif tipe $T G T$ dengan penggunaan media animasi lebih baik dari pada hasil belajar siswa yang hanya menggunakan model kooperatif tipe TGT tanpa penggunaan media animasi. Pada kelas eksperimen diperoleh nilai rata-rata hasil belajar pertemuan pertama yaitu 80,25 sedangkan pada pertemuan kedua didapatkan nilai rata-rata 87,43. Pada kelas kontrol diperoleh nilai rata-rata hasil belajar pertemuan pertama yaitu 70,26 sedangkan pada pertemuan kedua didapatkan nilai rata-rata hasil belajarnya 74,73 .

Berdasarkan uraian di atas, maka peneliti tertarik untuk mengangkat permasalahan ini dengan melakukan penelitian dengan judul: Pengaruh Penerapan Model Pembelajaran Kooperatif Tipe TGT (Team Games Tournament) dengan Media Molymod terhadap Hasil Belajar Siswa Kelas X di SMA YLPI Pekanbaru.

\section{METODE PENELITIAN}

Metode penelitian yang digunakan oleh peneliti adalah metode quasy eksperimen dengan membandingkan pengaruh penerapan model pembelajaran kooperatif TGT (Team Games Tournament) dengan media molymod pada kelas eksperimen dan metode ceramah pada kelas kontrol. Quasy eksperimen dapat digunakan minimal kalau dapat mengontrol satu variabel saja.[6]

$\begin{array}{crrr}\text { Tempat } & \text { yang } & \text { dipilih } & \text { untuk } \\ \text { penelitian } & \text { adalah } & \text { SMA } & \text { YLPI }\end{array}$
Pekanbaru. Penelitian ini dilaksanakan di kelas X (X 1 kelas eksperimen dan X 3 kelas kontrol) semester genap tahun ajaran 2015/2016 pada bulan Mei 2016.

Objek dalam penelitian ini adalah pengaruh penerapan model pembelajaran kooperatif tipe TGT (Team Games Tournament) dengan media molymod terhadap hasil belajar siswa SMA YLPI Pekanbaru, khususnya pada mata pelajaran Kimia pokok bahasan hidrokarbon. Subjek dalam penelitian ini adalah siswa kelas X SMA YLPI Pekanbaru tahun ajaran 2015/2016, yang akan kemudian dilakukan uji homogenitas.

Populasi dalam penelitian ini adalah siswa kelas X SMA YLPI Pekanbaru semester genap tahun ajaran 2015/2016 yang terdiri dari 4 kelas (X 1, X 2, X 3 dan $X$ 4) dengan jumlah siswa 138 orang. Sampel dalam penelitian ini adalah siswa kelas $\mathrm{X}$ SMA YLPI Pekanbaru semester genap yang diambil 2 kelas dari 4 kelas setelah dilakukan uji homogenitas. Satu kelas sebagai kelas eksperimen (X 1) dan satu kelas lagi sebagai kelas kontrol (X 3).

Pengambilan sampel ini menggunakan teknik probability sampling, yaitu simple random sampling. Simple random sampling dikatakan simple (sederhana) karena pengambilan anggota sampel dari populasi dilakukan secara acak tanpa memperhatikan strata yang ada dalam populasi itu. Cara demikian dilakukan bila anggota populasi dianggap homogen.[7]

Pada penelitian ini pengumpulan data dilakukan dengan cara tes, wawancara, angket dan dokumentasi. Tes adalah alat atau prosedur yang digunakan dalam rangka pengukuran dan penilaian.[8] Wawancara adalah cara untuk menghimpun bahan-bahan keterangan yang dilaksanakan dengan melakukan tanya jawab lisan secara sepihak, berhadapan muka dan dengan arah serta tujuan yang telah ditentukan.[9] Angket adalah suatu cara untuk mengumpulkan data dengan mengajukan pertanyaan tertulis kepada informan.[10] Serta dokumentasi adalah teknik pengumpulan data yang bersumber pada benda yang tertulis.

Sedangkan untuk analisis butir soal, terdiri atas validitas, reliabilitas, tingkat kesukaran dan daya pembeda soal. Validitas merupakan suatu ukuran yang menunjukkan kevalidan atau keshahihan suatu instrumen. Instrumen dikatakan 
valid jika instrumen tersebut dapat digunakan untuk mengukur apa yang seharusnya diukur.[11] Validitas yang digunakan dalam penelitian ini yaitu validitas isi dan validitas empiris. Tes hasil belajar mata pelajaran dapat dikatakan telah memiliki validitas isi, apabila tes tersebut dapat menjadi wakil yang representatif atau memadai bagi seluruh materi pelajaran yang telah diajarkan. Oleh karena itu, untuk memperoleh hasil tes yang valid, maka tes yang digunakan peneliti dikonsultasikan dengan guru bidang studi kimia yang mengajar di kelas $\mathrm{X}$ SMA YLPI Pekanbaru. Validitas empiris dapat dicari dengan menggunakan teknik korelasi point biserial, dimana angka indeks korelasi yang diberi lambang $r_{p b i}$ dapat diperoleh dengan menggunakan rumus:

$$
r_{p b i}=\frac{M_{p-M_{t}}}{S D_{t}} \sqrt{\frac{p}{q}}
$$

Reliabilitas adalah ketepatan atau tingkat presisi suatu ukuran atau alat pengukur. Untuk uji reliabilitas item tes menggunakan rumus Pearson Product Moment Metode Belah Dua Pembelahan Ganjil - Genap, yaitu dengan rumus:

$$
r_{b}=\frac{n\left(\sum X Y\right)-\left(\sum X\right) \cdot\left(\sum Y\right)}{\sqrt{\left(n \cdot \sum X^{2}-\left(\sum X\right)^{2}\right) \cdot\left(n \cdot \sum Y^{2}-\left(\sum Y\right)^{2}\right)}}[12]
$$

Soal yang baik adalah soal yang tidak terlalu mudah dan tidak terlalu sulit. Soal yang terlalu mudah tidak merangsang siswa untuk mempertinggi usaha memecahkannya. Sebaliknya soal yang terlalu sukar akan menyebabkan siswa menjadi putus asa dan tidak mempunyai semangat untuk mencoba lagi karena diluar jangkauannya.[13] Rumus untuk mencari indeks kesukaran soal adalah:

$$
\mathrm{P}=\frac{B}{J S}
$$

Analisis daya pembeda mengkaji butir-butir soal dengan tujuan untuk mengetahui kesanggupan soal dalam membedakan siswa yang tergolong mampu (tinggi prestasinya) dengan siswa yang tergolong kurang atau lemah prestasinya.[14] Rumus untuk menentukan indeks diskriminasi adalah:

$$
D=\frac{B_{A}}{J_{A}}-\frac{B_{B}}{J_{B}}=P_{A}-p_{B}
$$

Analisis data penelitian, terdiri atas analisis data awal (uji homogenitas), uji normalitas, analisis data akhir (uji hipotesis) serta penentuan nilai pengaruh $\left(\mathrm{r}^{2}\right)$ dan peningkatan Koefisien pengaruh (Kp). Analisa data awal dimulai dengan pengujian homogenitas varians menggunakan uji $\mathrm{F}$ dengan rumus:

$$
F=\frac{\text { Varians terbesar }}{\text { Varians terkecil }}
$$

Pengujian homogen varians dilakukan untuk memastikan bahwa kelompokkelompok yang dibandingkan merupakan kelompok-kelompok yang mempunyai nilai varians homogen.

Sedangkan untuk menghitung varians dari masing-masing kelompok digunakan rumus:

dan

$$
S_{1}^{2}=\frac{n\left(\Sigma X_{1}^{2}\right)-\left(\Sigma X_{1}\right)^{2}}{n_{1\left(n_{1}-1\right)}}
$$

$$
S_{2}^{2}=\frac{n\left(\Sigma X_{2}^{2}\right)-\left(\Sigma X_{2}\right)^{2}}{n_{2\left(n_{2}-1\right)}}
$$

Uji Normalitas bertujuan untuk menguji apakah sampel dalam penelitian ini berasal dari populasi yang normal atau tidak. Adapun rumus yang digunakan yaitu:

$$
\chi^{2}=\sum \frac{(f o-f e)^{2}}{f e}
$$

Teknik analisis data akhir (uji hipotesis) yang digunakan pada penelitian ini adalah dengan menggunakan $t$ tes dengan polled varians. Hal ini dikarenakan $\mathrm{n}_{1} \neq \mathrm{n}_{2}$ dan varians homogen maka rumus yang dapat digunakan $\mathrm{t}$ tes yaitu polled varians dengan $(\mathrm{dk})=\mathrm{n}_{1}+\mathrm{n}_{2}-{ }_{2}$.

$$
\mathrm{t}=\frac{\overline{X_{1}}-X_{1}}{\sqrt{\frac{\left(n_{1}-1\right) S_{1}^{2}+\left(n_{2}-1\right) S_{2}^{2}}{n_{1}+n_{2}-2}\left(\frac{1}{n_{1}}+\frac{1}{n_{2}}\right)}}
$$

Untuk mengetahui pengaruh terhadap hasil belajar siswa, maka dengan menghitung koefisien determinasi $\left(\mathrm{r}^{2}\right)$ menggunakan rumus: 


$$
\mathrm{r}^{2}=\frac{t^{2}}{t^{2}+\mathrm{n}-2}
$$

Sedangkan untuk melihat besarnya peningkatan koefisien pengaruh $(\mathrm{Kp})$ digunakan rumus:

$$
\mathrm{Kp}=\mathrm{r}^{2} \times 100 \%
$$

\section{HASIL DAN PEMBAHASAN}

Dalam penelitian eksperimen ini dibutuhkan dua sampel yang memiliki kemampuan homogen. Oleh karena itu perlu dilakukan tes uji homogenitas dengan memberikan soal tentang pokok bahasan sebelum materi penelitian yaitu redoks kepada keempat kelas $\mathrm{X}$ yaitu $\mathrm{X}$ 1, X 2, X 3 dan X 4. Dari keempat kelas tersebut hasil tes uji homogenitas dihitung menggunakan uji bartlet. Sehingga didapatlah bahwa semua kelas homogen. Peneliti memilih dua kelas untuk diteliti dengan menggunakan teknik random sampling, terpilih kelas $\mathrm{X}$ 1 sebagai kelas eksperimen dan X 3 sebagai kelas kontrol, kemudian pada kedua kelas tersebut dilakukan uji varians untuk mengetahui apakah dua kelas tersebut homogen. Hasil analisis menunjukkan nilai $\mathrm{F}_{\text {hitung }}=1,02085$ dan nilai $\mathrm{F}_{\text {tabel }}=1,80$ dan didapat bahwa $\mathrm{F}_{\text {hitung }}<\mathrm{F}_{\text {tabel }}$. Hal ini berarti kedua kelompok sampel mempunyai varians yang sama (homogen).

Instrumen dalam penelitian ini adalah soal yang digunakan untuk pretest dan posttest dengan soal berbentuk pilihan ganda. Sebelum digunakan sebagai instrumen dalam penelitian ini, soal diuji cobakan terlebih dahulu kepada kelas XI IPA 2 dengan jumlah siswa sebanyak 30 orang siswa. Hasil uji coba soal kemudian dianalisis untuk mengetahui validitas, reliabilitas, tingkat kesukaran, dan daya pembeda soal.

Validitas butir soal terdiri atas validitas isi dan validitas empiris. Berdasarkan hasil validitas isi yang diperoleh dari konsultasi dengan guru bidang studi kimia yaitu bapak Addarwadi Omar S.Pd, yaitu semua soal valid dikarenakan soal sesuai dengan indikator. Hasil analisis terdapat pada tabel berikut:
Tabel 1. Validitas Butir Soal

\begin{tabular}{ccccc}
\hline No & Kriteria & Nomor soal Jumlah & Persentase \\
\hline 1 & Valid & 1.30 & 30 & $100 \%$ \\
2 & Tidak valid & - & - & - \\
\hline & Jumlah & & 30 & 100 \\
\hline
\end{tabular}

Berdasarkan hasil analisis uji coba soal yang telah dilakukan dengan menggunakan rumus Spearman Brown, maka diperoleh reliabilitas tes sebesar 0,87 dengan kategori tinggi.

Berdasarkan hasil analisis uji coba tingkat kesukaran soal pada pokok bahasan hidrokarbon diketahui sebanyak $20 \%$ dengan kriteria sukar, $50 \%$ dengan kriteria sedang, $30 \%$ dengan kriteria mudah yang terangkum dalam tabel 2 berikut:

Butir soal yang dipilih peneliti untuk soal pretest dan posttest hanya diambil sebanyak 20 butir soal dengan pola perbandingan 3-5-2 artinya 30\% soal mudah $50 \%$ soal sedang dan $20 \%$ soal sukar. Soal kategori mudah yakni nomor 1, 10, 11, 16, 17 dan 20, soal kategori sedang yakni soal nomor 3, 4, $5,7,8,9,12,15,28$ dan 30, sedangkan soal kategori sukar adalah soal nomor 6, 18, 23 dan 26. Dapat dilihat pada gambar 2 berikut ini:

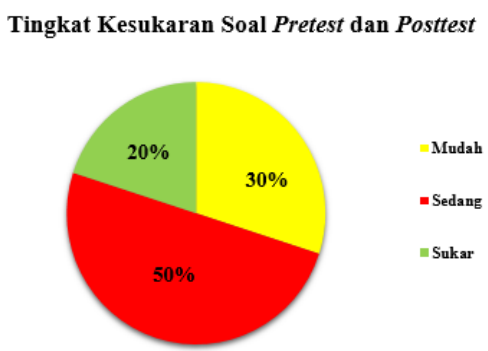

Gambar 2. Diagram Tingkat Kesukaran Soal Pretest dan Posttest

Berdasarkan hasil analisis uji coba pada pokok bahasan hidrokarbon diketahui sebanyak $10 \%$ dengan kriteria sangat jelek, 16,67\% dengan kriteria jelek, 43,33 \% dengan kriteria cukup, 26,67\% dengan kriteria baik dan 3,33\% dengan kriteria sangat baik yang terangkum dalam tabel 4 berikut: 
Tabel 4. Rangkuman Analisis Daya Pembeda Soal

\begin{tabular}{|c|c|c|c|c|}
\hline No & Kriteria & Jumlah & Nomor Butir Soal & Persentase \\
\hline 1 & Sangat jelek & 3 & $19,22,27$ & $10 \%$ \\
\hline 2 & Jelek & 5 & $13,21,24,25,29$ & $16,67 \%$ \\
\hline 3 & Cukup & 13 & $\begin{array}{l}1,2,3,6,10,12,14 \\
16,17,18,20,23,26\end{array}$ & $43,33 \%$ \\
\hline 4 & Baik & 8 & $5,7,8,9,11,15,28,30$ & $26,67 \%$ \\
\hline 5 & Sangat Baik & 1 & 4 & $3,33 \%$ \\
\hline & Jumlah & 30 & & $100 \%$ \\
\hline
\end{tabular}

Hasil analisis uji daya pembeda soal diperoleh sebanyak 3 soal $\left(\begin{array}{ll}10 & \%\end{array}\right)$ dengan kriteria sangat jelek, 5 soal $(16,67 \%)$ dengan kriteria jelek, 13 soal $(43,33 \%)$ dengan kriteria cukup, 8 soal $(26,67 \%)$ dengan kriteria baik dan 1 soal $(3,33 \%)$ dengan kriteria sangat baik. Dapat dilihat pada gambar 3 dibawah ini:

Gambar 3. Diagram Daya Pembeda

Soal

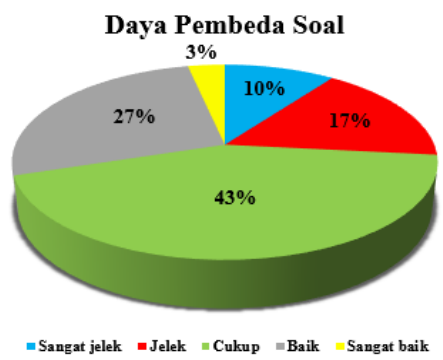

Setelah dilakukan analisis daya beda soal, maka diambil 20 soal dengan kriteria cukup, baik dan sangat baik. 20 butir soal ini peneliti gunakan sebagai instrumen dalam penelitian ini, atau untuk soal pretest dan posttest.

Dari 30 soal yang diujikan, hanya 20 soal yang diambil untuk dijadikan soal pretest dan posttest dengan kriteria memiliki daya beda cukup, baik dan sangat baik. Soal dengan kriteria daya pembeda jelek dan sangat jelek tidak diambil oleh peneliti untuk dijadikan soal pretest dan posttest.

Berdasarkan uji normalitas data, dapat diamati bahwa $\chi_{\text {hitung }}^{2}$ kelas eksperimen 3,4188 sedangkan $\chi_{\text {tabel }}^{2}$ untuk $\alpha=0.05 \%$ adalah 11,07 . Ternyata $\chi_{\text {hitung }}^{2}<\chi_{\text {tabel }}^{2}$ atau $3,4188<$ 11,07, maka data kelas eksperimen berdistribusi normal atau sampel yang berasal dari populasi yang berdistribusi normal.

Sedangkan untuk kelas kontrol dapat diamati bahwa $\chi_{\text {hitung }}^{2}$ kelas kontrol 6,1417 sedangkan $\chi_{\text {tabel }}^{2}$ untuk $\alpha=0,05$ $\%$ adalah 11,07. Ternyata $\chi_{\text {hitung }}^{2}<$ $\chi_{\text {tabel }}^{2}$ atau $6,1417<11,07$, maka data kelas kontrol berdistribusi normal atau sampel yang berasal dari populasi yang berdistribusi normal.

Besarnya peningkatan hasil belajar dapat dilihat dari rata-rata nilai pretest dan posttest pada kelas eksperimen dan kelas kontrol. Setelah kelas eksperimen diberi perlakuan dengan menggunakan model pembelajaran TGT (Team Games Tournament) dengan media molymod dan kelas kontrol dengan metode ceramah, ternyata pada kelas eksperimen nilai hasil belajar jauh lebih meningkat dibandingkan kelas kontrol. Awalnya nilai rata-rata pretest kelas eksperimen adalah sebesar 28,61 dan nilai rata-rata pretest kelas kontrol adalah sebesar 35,61 menjadi nilai ratarata posttest kelas eksperimen sebesar 77,36 adapun pada kelas kontrol dengan nilai rata-rata posttest sebesar 70,61 .

Perbandingan rata-rata nilai pretest dan posttest kelas eksperimen dan kelas kontrol dapat dilihat pada diagram dibawah ini:

\section{Rata-rata Nilai Pretest dan Posttest}

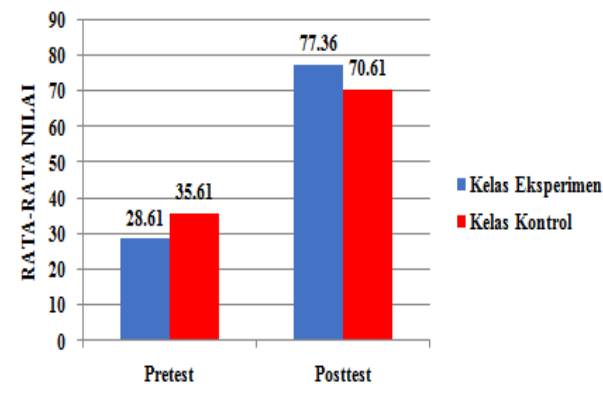

Gambar 7. Perbandingan Rata-rata

Nilai Pretest dan Posttest

Selanjutnya dihitung rata-rata selisih nilai pretest dan posttest pada kelas eksperimen dan kelas kontrol. Pada kelas eksperimen didapat rata-rata selisih nilai pretest-posttest sebesar 48,75 dan pada kelas kontrol rata-rata selisih nilai pretest-posttest sebesar 35 . Kemudian dilakukan uji menggunakan rumus tes " $\mathrm{t}$ " dan diperoleh nilai $\mathrm{t}_{\text {hitung }}=$ 
4,14 dan $t_{\text {tabel }}=2,00$ pada taraf signifikan $5 \%$ dan 2,65 pada taraf signifikan $1 \%$ yang menunjukkan $t_{\text {hitung }}>t_{\text {tabel }}$ sehingga Ha diterima dan $\mathrm{H}_{0}$ ditolak.

Hasil penelitian yang diperoleh sesuai dengan penelitian yang dilakukan oleh Wiwit, dkk, berdasarkan hasil penelitiannya menyimpulkan bahwa penerapan model pembelajaran kooperatif tipe $T G T$ dengan penggunaan media animasi lebih baik dari pada hasil belajar siswa yang hanya menggunakan model kooperatif tipe $T G T$ tanpa penggunaan media animasi. Dikarenakan dalam pembelajaran kooperatif tipe TGT, siswa belajar berkelompok dengan membahas materi pembelajaran bersama-sama. Sehingga apabila dalam kelompok ada anggota yang belum paham terhadap materi pembelajaran maka anggota yang lebih paham bertugas untuk mengajarkan materi yang belum dipahami oleh anggotanya yang lain. Selain itu, dalam pembelajaran kooperatif tipe TGT terdapat unsur permainan yang akan menuntut setiap anggota kelompok menjadi perwakilan kelompok untuk maju ke meja turnamen. Jadi, disini akan terjadi ketergantungan positif antar anggota kelompok, artinya usaha yang dilakukan oleh setiap anggota kelompok sangat perpengaruh terhadap keberhasilan kelompoknya.

\section{KESIMPULAN}

Berdasarkan hasil penelitian dan analisis data terhadap hasil belajar siswa dapat diambil kesimpulan bahwa Penerapan model pembelajaran kooperatif tipe TGT (Team Games Tournament) dengan media molymod dapat mempengaruhi hasil belajar siswa kelas $\mathrm{X}$ pada pokok bahasan hidrokarbon di SMA YLPI Pekanbaru. Hal ini dibuktikan melalui uji hipotesis dengan uji-t menunjukkan $t_{\text {hitung }}>t_{\text {tabel }}$ atau 4,14 $>2,00$ sehingga Ha diterima dan $\mathrm{H}_{0}$ ditolak.

Besarnya pengaruh terhadap hasil belajar siswa kelas $\mathrm{X}$ pada pokok bahasan hidrokarbon di SMA YLPI Pekanbaru dengan penggunaan model pembelajaran kooperatif tipe TGT
(Team Games Tournament) dengan media molymod adalah sebesar $20 \%$.

\section{REFERENSI}

[1] Hartono, dkk. PAIKEM. Pekanbaru: Zanafa Publishing. 2009. hlm. 17.

[2] Slameto. Belajar dan Faktor-Faktor yang Mempengaruhinya. Jakarta: Rineka Cipta. 2010. hlm. 98.

[3] Wiwit, dkk. Penerapan Model Pembelajaran Kooperatif Tipe TGT Dengan Dan Tanpa Penggunaan Media Animasi Terhadap Hasil Belajar Kimia Siswa SMA Negeri 9 Kota Bengkulu, ISSN 1412-3617, Jurnal Exacta, Vol. X No. 1, hlm. 71, Juni 2012.

[4] Restika Parendarti. (2016, 11 Februari) Aplikasi Model Pembelajaran Kooperatif tipe TGT (Team Games Tournament) dalam Meningkatkan Motivasi dan Hasil Belajar Biologi Siswa Kelas XII IPA SMA Muhammadiyah 2 Surakarta Tahun Ajaran 2008/2009 [Online]. $<$ http://etd.eprints.ums.ac.id/4278/2/ A420050042.pdf.

[5] Dewi Pratiwi dan Rini Muharini. Penerapan Model Pembelajaran Kooperatif Tipe Teams Game Tournament (TGT) Berbantuan Media Molymod Pada Materi Hidrokarbon Kelas X SMA Negeri 4 Singkawang. Universitas Tanjungpura: Prodi Pendidikan Kimia, Jurusan FMIPA, FKIP. hlm. 46-47.

[6] Nana Syaodih Sukmadinata. Metode Penelitian Pendidikan. Bandung: Remaja Rosdakarya. 2012. hlm. 207.

[7] Sugiyono. Metode Penelitian Pendidikan Pendekatan Kuantitatif, Kualitatif, dan $R$ \& D. Bandung: Alfabeta. 2008. hlm. 120.

[8] Anas Sudijono. Pengantar Evaluasi Pendidikan. Jakarta: PT. Raja Grafindo Persada. 2011. hlm. 66.

[9] Mas'ud Zein dan Darto. Evaluasi Pembelajaran Matematika. Pekanbaru: Daulat Riau. 2012. hlm. 49.

[10] Nursalim. Teknik Penulisan Karya Ilmiah. Pekanbaru: Zanafa Publishing. 2011. hlm. 19. 
[11] Sugiyono. Metode Penelitian Kuantitatif, Kualitatif Dan $R \& D$. Bandung: Alfabeta. 2014. hlm. 121.

[12] Riduwan. Belajar Mudah Penelitian. Bandung: Alfabeta. 2013. hlm. 103.

[13] Suharsimi Arikunto. Dasar-dasar Evaluasi Pendidikan. Jakarta: Bumi Aksara. 2007. hlm. 207.

[14] Nana Sudjana. Penilaian Hasil Proses Belajar Mengajar. Bandung: Remaja Rosdakarya. 2008. hlm. 141.

[15] Abdul Majid. Strategi Pembelajaran. Bandung: Remaja Rosdakarya. 2007. hlm. 188. 